\title{
The Role of Moderating Factors in Mobile Coupon Adoption: An Extended TAM Perspective
}

\author{
Sudarsan Jayasingh ${ }^{1}$ and Uchenna Cyril Eze ${ }^{2}$ \\ ${ }^{1}$ School of Business and Enterprise, Swinburne University of Technology, Kuching, Malaysia \\ ${ }^{2}$ Faculty of Business and Law, Multimedia University, Melaka, Malaysia
}

\begin{abstract}
This research represents a theoretical extension of the extended Technology Acceptance Model (TAM) to study the consumer adoption of mobile coupons. We developed a model to test the relationship between theoretical constructs spanning technological and cognitive influence processes and their impact on Behavioural Intention. This study aims to integrate price consciousness and value consciousness into the promotional effectiveness framework. The results of the study indicate that perceived usefulness and perceived ease of use influence attitude, which in turn influences the intention to use m-coupons. Social influence and compatibility play a major role in influencing the intention to use mobile coupons. The key objective of this research paper is to study the role of value consciousness and price consciousness as moderating variable in predicting the customer intention to use mobile coupons. The high value conscious and price conscious customers indicate more interest in redeeming m-coupons than other customers. This result confirms that in the mobile technology context, traditional adoption models such as TAM could be applied but needs to be modified and extended in order to increase their prediction and explanation power.
\end{abstract}

Keywords: Mobile Coupons, Discount Coupons, extended TAM, and Mobile Marketing

\section{Introduction}

Mobile Marketing, which can be called the next generation of eMarketing, is more and more common in today's society. The mobile marketing is growing at a much faster rate because it is considered more cost effective, personalized, and results-driven. The advent of mobile marketing has resulted in a new form of sales promotion. Now, advertisers are deploying digital coupons on mobile phones, aiming to exploit the inherent location and real time delivery capabilities that make for a more compelling solution than traditional paper coupons. Juniper Research forecasted that 200 million mobile subscribers globally will use mcoupons by 2013 (Neil, 2008)

A mobile coupon (m-coupon) is an electronic ticket solicited and/or delivered by mobile phone that can be exchanged for a financial discount or rebate when purchasing a product or service (MMA, 2007). They can carry messages including text, pictures, audio, and, more recently, even videos. The consumer receives the coupon on the mobile device and stores it there until he or she decides to redeem it. Currently, many businesses are using this new mobile channel to create new opportunities. The mobile operators and other service organizations are providing a new service called "mobile coupons," enables the downloading of coupons offered by different outlets onto the mobile phones for use later. At present, the m-coupon market is still in its growth stage and it seems the business opportunities for it are limitless.

The prevailing view that coupon effectiveness is contingent upon certain consumer characteristics has received limited empirical follow-up (Lichtenstein, Netemeyer, and Burton 1990; Guimond, Kim, and Laroche, 1999).

Copyright (C) 2010 Sudarsan Jayasingh and Uchenna Cyril Eze. This is an open access article distributed under the Creative Commons Attribution License unported 3.0, which permits unrestricted use, distribution, and reproduction in any medium, provided that original work is properly cited.

Author contact: Sudarsan Jayasingh e-mail: sjayasingh@swinburne.edu.my 
Lichtenstein et al (1990) provided evidence that value consciousness and coupon proneness are distinct constructs that both underlie coupon redemption behaviours. The present study, focus on the interaction between coupon, technology acceptance and consumer characteristics. Consumer segment differences likely to vary in their responsiveness to sales promotions and would determine the most effective form of policy for reaching target consumer segments (Kukar-Kinney and Grewal, 2007). The goal of the current research is to fill this gap in knowledge about consumer responses to sales promotions incorporating price consciousness and value consciousness in the analysis. Although consumers' level of price / Value consciousness has been extensively discussed, there is limited research to date examining its moderating effect on the effectiveness of promotional actions (Palazon and Delgado, 2009).

Mobile coupons previously the biggest barrier to entry was the technology. It seems that they are facing another challenge now: consumer adoption. Even though there are considerable researches on mobile services, but there are not many studies on mobile coupons. With a few notable exceptions (e.g., Hsu, Wang, and Wen, 2006; Dickinger and Kleijnen, 2008), little research has been devoted to explore the factors that contribute to consumers' willingness to adopt mobile couponing. Little is still known about consumers' attitudes toward adopting, or not adopting, and factors that influence consumers' attitudes and value perceptions about them. It is likely that the new media environment would alter consumers' couponing behaviour identified in previous research.

This research explores in-depth the characteristics and behaviour of the coupon prone customers, this research contributes to a better understanding of how personal factors strengthen or attenuate behaviour toward mobile coupons. However, little attention is given to relatively new type of coupons like mobile coupons. This study, therefore, seeks to analyze whether the behavioural attitude and intention of consumers using $\mathrm{m}$-coupons shows the same result as that from traditional discount coupons and whether there is a difference in influential factors.

\section{Literature Review}

\subsection{Print Coupon Redemption Behaviour}

There is a continuing debate about the determinants of coupon use. Many researchers have sought to explain coupon deal redemption in terms of the socioeconomic and demographic characteristics of consumers or to identify the psychological factors that motivate consumers to use coupons (Narasimhan, 1984; Blattberg, and Neslin, 1990; Bawa, Srinivasan and Srivastava, 1997). Although they have contributed a lot to our understanding of coupon redemption behaviour, there is no coherent evidence for the effectiveness of coupon programs (Mittal, 1994). Many researchers have sought to identify the characteristics of coupon-prone or deal-prone consumers. According to Bawa, Srinivasan and Srivastava (1997) there are five factors that might affect consumer response to coupons. They are: a) coupon characteristics, b) mailer characteristics c) brand characteristics d) product characteristics and consumer characteristics.

Shimp and Kavas (1984) applied Ajzen and Fishbein theory of reasoned action to conceptualise coupon usage. They found that both personal attitudes and subjective norms played major roles in determining intentions to use coupons. Bagozzi, Baumgartner and Yi (1992)] studied the intentions to redeem a coupon and the act of coupon redemption. They found that coupon usage was influenced jointly by consumers' self-efficacy (confidence in the ability to use coupons), instrumental beliefs (beliefs that it should lead to a favourable outcome) and affect toward means (liking for the act). All these findings together suggest that by paying attention to the design of the direct mail coupon promotion, manufacturers may be able to increase coupon usage through reinforcing the perceived benefits, reducing the perceived costs and strengthening the link between intentions and redemption behaviour (Bawa, Srinivasan and Srivastava, 1997).

Bonniei, Campbell and Fredenberger (1996) used factor analysis to identify the underlying factors that deter consumers from coupon redemption. Their study reveals that consumers perceive couponed products to be of low quality and feel embarrassed to use coupons in their shopping activities. Coupon usage increases, as one perceives higher satisfaction and pride with the use of coupons (Babakus, Tat, and Cunningham, 1988). Han, Yoon and Cameron (2001) investigated how web user's attitude, intention and behaviour in using online coupons are affected by offline coupon attitude. The results indicate that all three independent 
Table 1: Researches on Mobile Service Adoption

\begin{tabular}{|c|c|c|c|}
\hline Author/s & $\begin{array}{l}\text { Technology and } \\
\text { Application }\end{array}$ & $\begin{array}{l}\text { Basic Model } \\
\text { Used }\end{array}$ & Key Variables \\
\hline Pedersen (2002) & $\begin{array}{ll}\text { Mobile } & \text { Internet } \\
\text { Services } & \\
\end{array}$ & TAM and TPB & PU, PEOU \\
\hline Hung et al. (2003) & Mobile Commerce & TAM & PU, PEOU \\
\hline Muk (2004) & SMS Advertising & TRA & Attitude, Subjective Norms \\
\hline Han (2005) & $\begin{array}{l}\text { Mobile Medical } \\
\text { Information System }\end{array}$ & TAM & PU, PEOU, PIIT, COM \\
\hline $\begin{array}{l}\text { Kleijnen, Wetzels and Ruyter } \\
\text { (2004) }\end{array}$ & Wireless Finance & TAM & PU, PEOU, SI, PSQ \\
\hline Bedford (2005) & Mobile Commerce & UTAUT & Trust, PE, EE, SI, FC \\
\hline Lin and Wang (2005) & Mobile Gaming & TAM & $\begin{array}{l}\text { PU, PEOU, PC, Self Efficacy, } \\
\text { Financial Resources }\end{array}$ \\
\hline Hsu, Wang and Wen (2006) & Mobile Coupons & Decomposed TPB & COM. PIIT, PEOU, PU, SI \\
\hline $\begin{array}{l}\text { Dickinger and Kleijnen } \\
\text { (2008) }\end{array}$ & Mobile Coupons & TAM & $\begin{array}{l}\text { Price consciousness } \\
\text { Fear of Spam } \\
\text { Economic benefits } \\
\text { Coupon Proneness } \\
\text { Past use of coupons } \\
\text { Redemption Effort }\end{array}$ \\
\hline Shen and Chen (2008) & Mobile Advertising & TPB & PU, PEOU \\
\hline Tao (2008) & Mobile Commerce & & Privacy \\
\hline Shen and Chen (2008) & Mobile Advertising & TAM & PU, PEOU \\
\hline Koury (2008) & Mobile Advertising & TAM2 & Social Norms \\
\hline
\end{tabular}

variables affect web users' attitude and intention to use online coupons, but do not affect their online couponing behaviour.

\subsection{Mobile Coupon Redemption Behaviour}

A number of researchers have studied user acceptance of mobile technology and services such as the mobile Internet, text messaging, contact services, mobile payment, mobile gaming and mobile parking services based on IS adoption models. Pedersen (2002) conducted an exploratory study about early adopters' behaviour with regard to using mobile Internet services. He decomposed the TAM and the TPB to build a new research model in order to understand the phenomena. He found that, at least from a measurement perspective, adoption research models might successfully be applied to the study of mobile service adoption. However, he argued that simple IS adoption research models, e.g. the TAM, should be extended with both subjective norms and behavioural control in attempts to explain the adoption of mobile commerce services. He further recommended that his model could be modified when applied to study other mobile commerce services (Pedersen, 2002).
Kwon and Chidambaram (2000) used the TAM to investigate patterns of cellular phone adoption and usage in an urban setting. The results of their study confirmed that users' perceptions influence their behaviour towards cellular phones, specifically, the perceived ease of use. Hung, Ku and Chang (2003) used the TAM for evaluating the acceptance and usage of mobile commerce by collecting data from students. The perceived usefulness and ease of use were found to have positive impacts on the users attitudes and behavioural intention. Lapczynski (2004) integrated four technology acceptance models (TAM, TAM2, TPB, TTF) and created a robust model for mobile computing devices. He added three new factors (adaptability, mobility, and security) that act as antecedents of perceived usefulness, which is one of two foundational belief constructs in technology acceptance model theory.

Kleijnen, Wetzels and Ruyter (2004) investigated consumer acceptance of wireless finance and found that the variables of perceived cost, system quality and social influence correlated significantly with attitude towards use. The variables such as participants' age, computer skills, mobile technology 
readiness and social influence proved to have moderating effects in the mobile phone usage context. Social Influence was added to the model, and found to display significant effect on BI. Bedford (2005) used UTAUT model to investigate acceptance and use of $\mathrm{m}$-commerce. He added trust as one of determinant of behaviour intent. The trust factor increased the total variance of basic model by $2 \%$. Lin and Wang (2005) tested integrated TAM model by adding, perceived credibility, perceived selfefficacy" and perceived financial resources. The results support the integrated model in predicting consumers' intention to use mcommerce.

Hsu, Wang and Wen (2006) studied the factors influencing attitude and behavioural intentions of consumers using m-coupons using decomposed theory of planned behaviour. The results of the study demonstrate that personal innovativeness has no direct relation to behavioural attitude. Behaviour and attitude of consumers are largely influenced by endorsement of family and friends. Shen and Chen (2008) used an integrated research model (TPB) to explore the factors that influence consumer intention of using mobile advertising in China. Existing knowledge, perceived usefulness and perceived ease of use all had positive effects on consumers' usage intention. Amin extends the applicability of the technology acceptance model (TAM) to mobile phone credit cards and includes "perceived credibility (PC)", the "amount of information about mobile phone credit cards (AIMCs)" and "perceived expressiveness (PE)", in addition to "perceived usefulness (PU)" and "perceived ease of use (PEOU)". The results indicate that PU, PEOU, PC and the amount of information contained on mobile phone credit cards are important determinants to predicting the intentions of Malaysian customers to use mobile phone credit cards (Amin, 2007).

The results of these studies confirm that in the mobile technology context, traditional adoption models such as TAM could be applied, but need modification and extension in order to increase their prediction and explanation power (Han, 2005). The finding from these studies regarding mobile phone emphasis that social factors, perceived credibility compatibility and personal innovativeness should be included in the basic TAM model.

\subsection{Researches on Coupon Proneness, and Price Consciousness}

Most of coupon research study involves a disaggregate-level analysis concentrating on the individual consumer's demographic and psychological correlates (e.g., deal proneness, coupon attitudes, brand loyalty, and coupon proneness) of coupon redemption behavior (Pedersen, 2002; Mittal, 1994; Guimond, Kim, and Laroche, 1999). Lichtenstein et al. (1990) research findings show that consumers' coupon redemption behaviours are induced by value consciousness rather than coupon proneness.

Price consciousness is defined as "the degree to which the consumer focuses exclusively on paying a low price" (Lichtenstein et al., 1990). Therefore, price conscious consumers are concerned about searching for a low price in the marketplace, and they derive emotional value and entertainment from shopping for lower prices (Alford and Biswas, 2002). Consumer price consciousness has been regarded as a key issue in sales promotions and store brand purchases. For example, Aliawadi et al. found that store brand purchases in particular were associated with price consciousness (Ailawadi, Neslin and Gedenk, 2001). Sinha and Batra (1999) also found that price consciousness was a significant reason driving consumers to buy store brands in some categories more often than in others. In particular, prior research in sales promotions has suggested that price consciousness moderated the effects of low price guarantees on consumers' pre-purchase evaluations, behavioral intentions (Dutta and, Biswas, 2005), and store loyalty (Kukar-Kinney and Walters, 2003).

Therefore, different consumer segments can be distinguished based on their price consciousness (e.g., high vs low). The research results reported by Palazon and Delgado (2009) indicate that price consciousness is a key consumer trait because it moderates the effectiveness of price discounts and premiums at moderate and high benefit levels.

\section{Research Model and Hypothesis}

The success of mobile coupons hinges on consumer's willingness to adopt new technology and engage in activities using systems and devices different from what they have used in the past. To be precise, eight important determinants of technology acceptance are studied: perceived usefulness (PU), perceived ease of use (PEOU), social influence (SI) compatibility (COMP), perceived credibility (PC) and personal innovativeness (PI), coupon proneness (CP), mobile coupon attitude (ATT). 
Value Consciousness and Price Consciousness acts as the moderating variable for coupon redemption behaviour.

$\mathbf{H}_{1}$. The perceived usefulness by the consumer has a positive effect on their attitude towards using m-coupons.

$\mathbf{H}_{2}$ : The perceived ease of use by the consumer has a positive effect on their attitude towards using m-coupons.

$\mathbf{H}_{3}$ : The coupon proneness of the consumer has a positive effect on their attitude towards using m-coupons.

$\mathbf{H}_{4}$ : The perceived credibility by the consumer has a positive effect on their attitude towards using m-coupons.

H5: The Personal Innovativeness of the
consumer has a positive effect on the

behavioural intention towards using $m$ coupons.

$\mathbf{H}_{6}$ : The Social Influence has a positive effect on the behavioural intention towards using $\mathrm{m}$ coupons.

H: The compatibility of the consumer in using mobile phone has a positive effect on the behavioural intention towards using $\mathrm{m}$ coupons.

H8: The mobile coupons attitude has a positive effect on the behavioural intention towards using m-coupons.

H9: The effect exerted by PU, PEOU on Attitude is greater for high value conscious customers.

H10: The effect exerted by PU, PEOU on Attitude is greater for high price conscious customers.

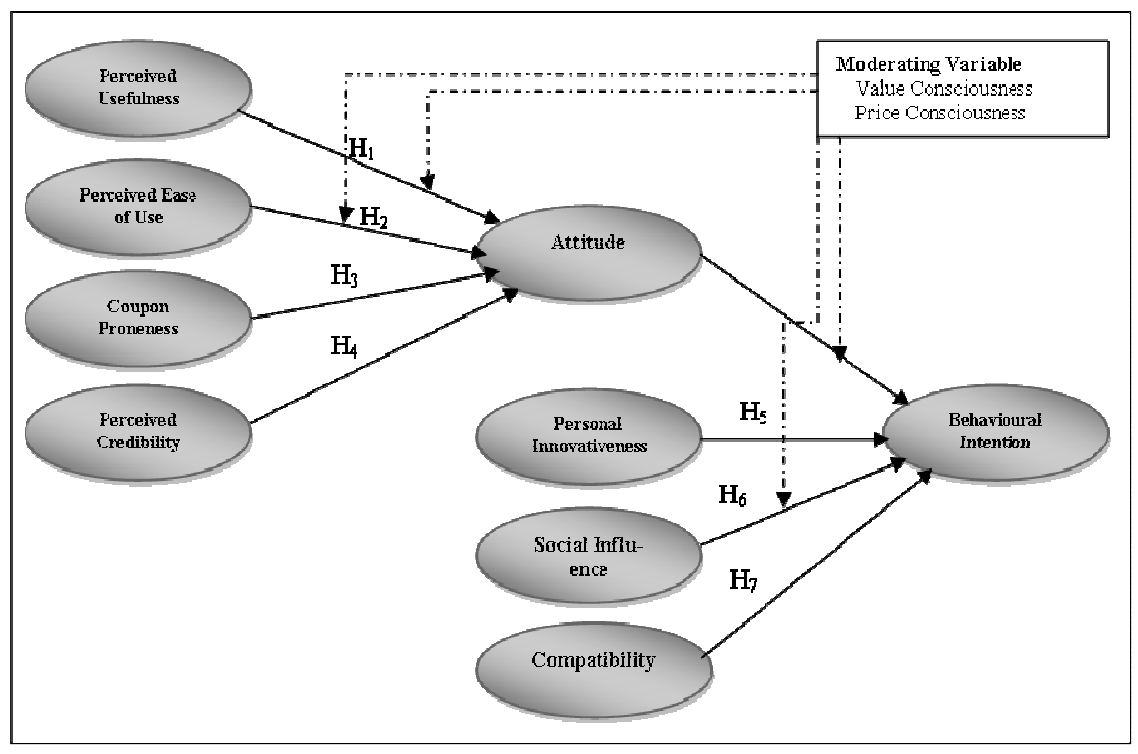

\section{Methodology}

A pre-test was conducted to validate the instrument. Feedback about the layout of the questionnaire and question ambiguity was obtained. Some changes were made to the questionnaires as deemed appropriate. The revised questionnaires were distributed to 1000 participants as noted earlier. The sample of this research was drawn from major cities of Malaysia. A stratified sampling method was used for this study. The whole population is divided into four strata's based on total number of mobile phone users. Proportionate allocation was made in each of the strata that is proportional to that of the total population.

The areas covered for the survey are Selangor, Kuala Lumpur, Johor and Sarawak. These areas are selected based on the number of hand phone users in Malaysia. 22.1\% of hand phone users are located in Selangor, $13.5 \%$ in Johor, $8 \%$ in Sarawak and $8.6 \%$ in Kuala Lumpur (MCMC, 2008). 
Table 2: Profile of Respondents

\begin{tabular}{|c|c|c|c|c|c|}
\hline Variable & Frequency & $(\%)$ & Variable & Frequency & $(\%)$ \\
\hline $\begin{array}{l}\frac{\text { Gender }}{\text { Female }} \\
\text { Male }\end{array}$ & $\begin{array}{l}374 \\
407\end{array}$ & $\begin{array}{l}48 \\
52\end{array}$ & $\begin{array}{l}\text { Location } \\
\text { Selangor and KL } \\
\text { Johor } \\
\text { Sarawak }\end{array}$ & $\begin{array}{l}463 \\
171 \\
147\end{array}$ & $\begin{array}{l}59 \\
22 \\
19\end{array}$ \\
\hline $\begin{array}{l}\text { Household Income: } \\
\text { Under RM } 2000 \\
\text { RM } 2001 \text { - RM } 4000 \\
\text { RM } 4001 \text { - RM } 6000 \\
\text { RM } 6001 \text { - RM } 8000 \\
\text { RM } 8001 \text { - RM } 10000 \\
\text { RM } 10001 \text { and Above }\end{array}$ & $\begin{array}{l}331 \\
216 \\
134 \\
45 \\
18 \\
24\end{array}$ & $\begin{array}{l}42 \\
28 \\
17 \\
6 \\
2 \\
3 \\
\end{array}$ & $\begin{array}{l}\text { Age } \\
\text { Under } 18 \\
19 \text { to } 25 \\
26 \text { to } 33 \\
34 \text { to } 41 \\
42 \text { to } 48 \\
\text { Above } 50\end{array}$ & $\begin{array}{l}31 \\
482 \\
223 \\
36 \\
6 \\
3\end{array}$ & $\begin{array}{l}4.0 \\
61.5 \\
28.5 \\
4.5 \\
1.0 \\
0.5\end{array}$ \\
\hline $\begin{array}{l}\text { Race } \\
\text { Malay } \\
\text { Chinese } \\
\text { Indian } \\
\text { Others }\end{array}$ & $\begin{array}{l}396 \\
275 \\
73 \\
37\end{array}$ & $\begin{array}{l}51 \\
35 \\
09 \\
05\end{array}$ & $\begin{array}{l}\text { Total Number of } \\
\text { Respondents }\end{array}$ & 781 & 100 \\
\hline
\end{tabular}

Table 3: Convergent Validity and Internal Consistency Reliability

\begin{tabular}{|c|c|c|c|}
\hline Description & Item & $\begin{array}{l}\text { Cron- } \\
\text { bach al- } \\
\text { plua }\end{array}$ & Based On \\
\hline Percairgd Usefiulnoss & 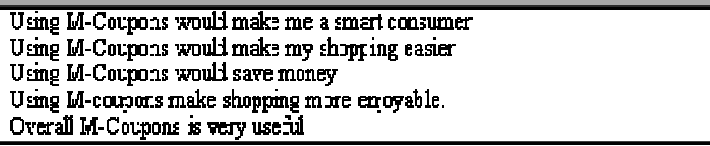 & {$[.963$} & $\begin{array}{l}\text { Venkatesin and } \\
\text { Dans, :596 [35] }\end{array}$ \\
\hline Perceived Ease of Use & 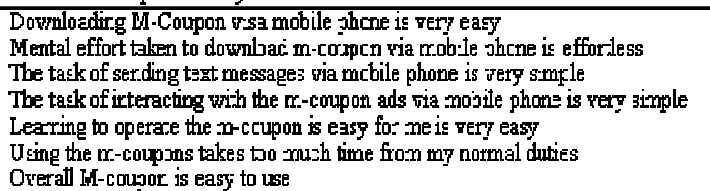 & {$[.952$} & $\begin{array}{l}\text { Venkatesin and } \\
\text { Dans, }: 596\lceil 35\rceil\end{array}$ \\
\hline Personal Imorrativenes & 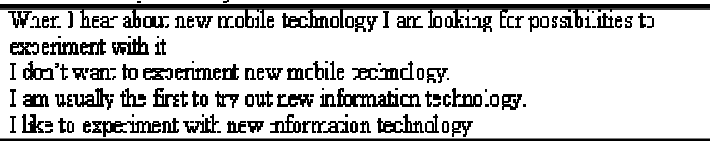 & {$[.856$} & Han, $2005 \mid 27$ \\
\hline Cnumm Prnnempss & 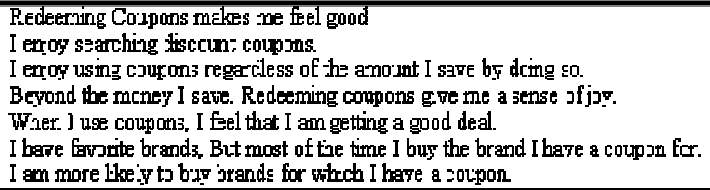 & 09444 & 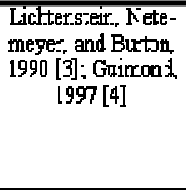 \\
\hline Sorial Influonce & 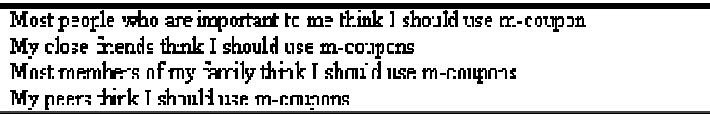 & {$[.934$} & $\begin{array}{c}\text { Shimp de Kampos } \\
1984[13]\end{array}$ \\
\hline Pereched Credbillty & 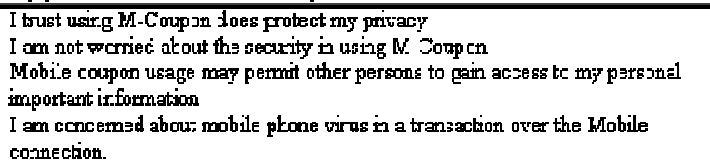 & {$[.926$} & $\begin{array}{l}\text { Pidesraingx ot al, } \\
\text { 2001 [35] }\end{array}$ \\
\hline Conpattbilltry & 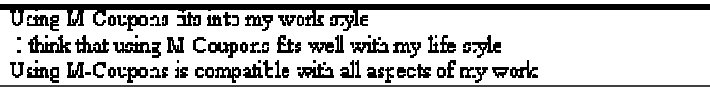 & [.0:7 & Hanc, $2005[27]$ \\
\hline Mobile ComponAtttude & $\begin{array}{l}\text { Beti- Guvt } \\
\text { Fuüist - Tfise } \\
\text { IIar-nful - benz-ficial } \\
\text { Not attacire - ittactive } \\
\text { Ead - IIappy }\end{array}$ & 6.957 & $\begin{array}{c}\text { Karw, 1981 } \\
\text { Slin:-ry \& Kalros } \\
1984[13]\end{array}$ \\
\hline Behavioural [ntention & 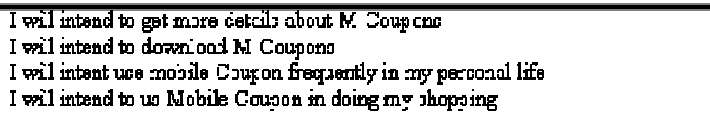 & {$[.962$} & $\begin{array}{l}\text { Varlsatcah Morri; } \\
\text { Dars aril Davis; } \\
\quad 2003[36]\end{array}$ \\
\hline
\end{tabular}


There were 824 returned responses, for an overall response rate of $82.4 \%$ from the total number of participants; there were 43 invalid returned responses, which were eliminated before final the data analysis. The reason for nonparticipation was mainly due to lack of time to complete the survey. Fifty-two percent of the completed surveys were from male respondents. Majority of the respondents (91\%) belong to the age group of $19-33$ years old. $45 \%$ of the respondents' monthly income range from RM2000 to RM6000.

\section{Data Analysis and Results}

\subsection{Measurement Model}

Based on the literature review, the hypotheses have been conceptualized in the structural model presented in Fig. 1. A confirmatory factor analysis using AMOS 16 was conducted to test the measurement model. The Cronbach alpha's for all the constructs were more than 0.8 and exceeded the suggested value of 0.70 recommended by Hair et al. (2006). The result demonstrated the survey results have high reliability and ensure a proper ground for further analysis. In this section, we will first examine the measurement model and then assess the structural model by following the two-step analytical procedures. As shown in Table 5, all the model-fit indices exceeded their respective common acceptance levels, suggested by previous research, and thus demonstrating that the measurement model exhibited a fairly good fit with the data collected.

Reliability and convergent validity of the factors were estimated by composite reliability; average variance extracted and factor loadings (See Table 4) (Hair et al., 2006). The composite reliability was estimated to evaluate the internal consistency of the measurement model. The composite reliabilities of the measures included in the model ranged from 0.7500 to 0.8747 . All were greater than the benchmark of 0.70 recommended by Hair et al. (2006). The average variance extracted of the measures included in the model ranged from 0.6081 to 0.8443 . A variance extracted of greater than 0.50 indicates that the validity of both the construct and the individual variables is high (Hair et al., 2006).

Table 4: Factor loading, composite reliability and average variance extracted

\begin{tabular}{|c|c|c|c|c|}
\hline Construct & Item & Factor loading & $\begin{array}{l}\text { Composite } \\
\text { Reliability }\end{array}$ & $\begin{array}{c}\text { Aver age Variance } \\
\text { Extracted }\end{array}$ \\
\hline \multirow[t]{5}{*}{ Percelved usefulness } & PUa & 0.910 & \multirow{5}{*}{0.8333} & \multirow{5}{*}{0.8443} \\
\hline & PUb & 0.921 & & \\
\hline & PUe & 0.916 & & \\
\hline & Pागत & 1) प्रक & & \\
\hline & PUc & 0.911 & & \\
\hline \multirow{7}{*}{$\begin{array}{c}\text { Perceived Ease uI } \\
\text { Use }\end{array}$} & PEOUy & 0.856 & \multirow{7}{*}{0.8746} & \multirow{7}{*}{0.7413} \\
\hline & PFothh & 0891 & & \\
\hline & PEOUC & 0.892 & & \\
\hline & PEOUd & 0.905 & & \\
\hline & PEOTIe & 0.911 & & \\
\hline & FEOJf & 0.745 & & \\
\hline & $\mathrm{PEOU}_{8}$ & 0.825 & & \\
\hline \multirow[t]{7}{*}{ Coupon Pronemes } & $\mathrm{CPa}$ & 0.868 & \multirow{7}{*}{$(1,8 / 4)$} & \multirow{7}{*}{ 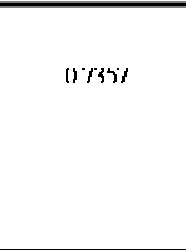 } \\
\hline & $\mathrm{CPb}$ & 0.88 & & \\
\hline & CFC & 0.870 & & \\
\hline & CPd & 0.891 & & \\
\hline & CPE & 0.894 & & \\
\hline & (!Pf & 18133 & & \\
\hline & $\mathrm{CP}_{\mathrm{B}}$ & 0.828 & & \\
\hline \multirow[t]{4}{*}{ Percelved Credlbllily } & SECy & 0.941 & \multirow{4}{*}{0.7998} & \multirow{4}{*}{$0 . \infty 012$} \\
\hline & SECh & 0.855 & & \\
\hline & FRIa & 0.905 & & \\
\hline & PRTB & 0.877 & & \\
\hline \multirow[t]{5}{*}{ Attltade } & Atta & 0.838 & \multirow{5}{*}{0.8332} & \multirow{5}{*}{0.7289} \\
\hline & Attb & 0.808 & & \\
\hline & Attc & 0.863 & & \\
\hline & Attd & 0.898 & & \\
\hline & Atte & 0.859 & & \\
\hline \multirow[t]{3}{*}{ Compatibility } & COMB & 0.893 & \multirow{3}{*}{0.7500} & \multirow{3}{*}{0.8319} \\
\hline & COMb & 0.922 & & \\
\hline & COMs & 0.921 & & \\
\hline \multirow[t]{4}{*}{ Sncigl Influpencre } & 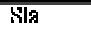 & (1) क्रुम & \multirow{4}{*}{0.7999} & \multirow{4}{*}{0.7709} \\
\hline & Ellb & 0.908 & & \\
\hline & SIC & 0.888 & & \\
\hline & S्ञान & 0.887 & & \\
\hline \multirow{4}{*}{$\begin{array}{c}\text { Personal } \\
\text { Innovatlvencss }\end{array}$} & $\overline{F I} a$ & 0.700 & \multirow{4}{*}{0.7093} & \multirow{4}{*}{0.6081} \\
\hline & PIb & 0.812 & & \\
\hline & $\overline{\text { PIc }}$ & 0.838 & & \\
\hline & PId & 0.762 & & \\
\hline \multirow{4}{*}{$\begin{array}{l}\text { Behavioural } \\
\text { Intention }\end{array}$} & $\overline{\text { BTa }}$ & 0.889 & & \\
\hline & $\mathrm{BIb}$ & 0.925 & 0.7999 & 0.8599 \\
\hline & BIC & 0.941 & & \\
\hline & मात & 0.953 & & \\
\hline
\end{tabular}




\subsection{Structural model}

Comparison of all fit indices, with their corresponding recommended values, provided evidence of a good model fit. Properties of the causal paths, including standardized path coefficients, t-values, and variance explained for each equation in the hypothesized model are presented.

The results indicate that all the hypotheses for the core model can be confirmed. Properties of the causal paths, including standardized path coefficients, $t$-values and variance explained, for each equation in the hypothesized model, are presented in Figure 2 and Table 8. As expected, hypotheses $\mathrm{H} 1, \mathrm{H} 2, \mathrm{H} 3, \mathrm{H} 4 \mathrm{H} 5, \mathrm{H} 6, \mathrm{H} 7$ and $\mathrm{H} 8$ were supported in that perceived usefulness, perceived ease of use, coupon proneness and perceived credibility, had a significant effect on m-coupon attitude. Mobile coupon attitude, Compatibility, Social Influence and personal influence has direct effect on mobile coupon intention to use. They account for 66.5 percent of the variance in behavioral intention. Perceived usefulness strongly determines the attitude to use m-coupons. Perceived usefulness
( $\beta=0.491$ ) contributing more to mobile coupon attitude to use then perceived ease of use $(\beta=0.171)$, and coupon proneness $(\beta=0.09)$, and perceived credibility $(\beta=0.17)$. Attitude $(\beta=0.57)$ strongly determines the intention to use mobile coupons followed by social influence $(\beta=0.22)$ and Compatibility $(\beta=0.21)$.

\subsection{Test of Moderating Effect}

We identified segments using cluster analysis of price consciousness construct. We used SPSS software to perform two step cluster analysis. The cluster solution leads to a group of 269 value seeking customers' and 512 Non value consciousness customers. These two clusters serve as a grouping variable for a multiple group analysis. As we perform a cluster analysis and use the results for multiple group Structural Equation Modelling analysis. Hypotheses about the moderating effects of user variables were tested by comparing path coefficients between the two groups produced for each moderator using t-value. In the case of t-value over 1.96 (over 95\% confidence), we conclude the coefficient has moderator effect.

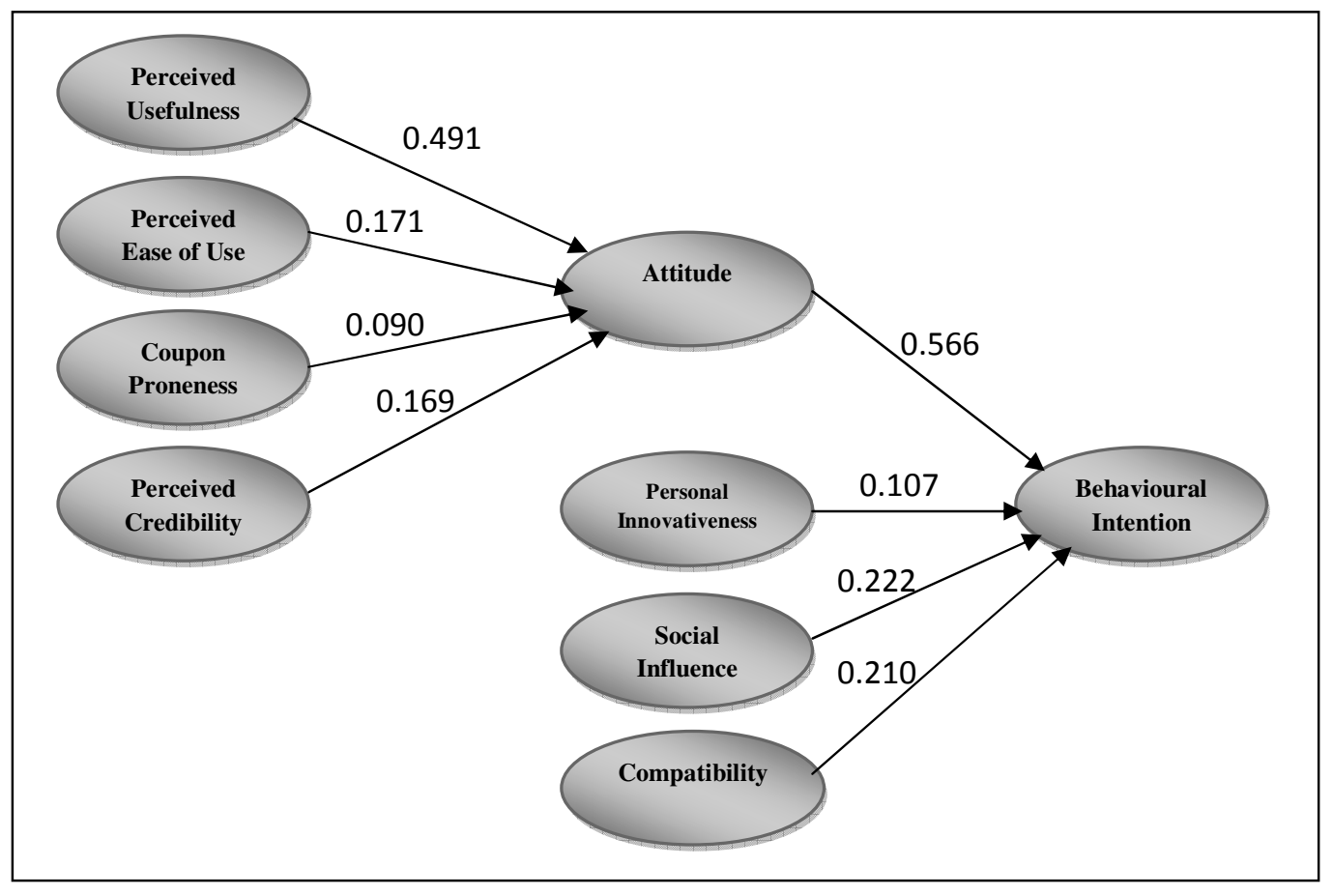

Figure 2. Structural model of Behavioral intention to use m-coupons 
Table 5: Results of Moderating Effects of Price Consciousness

\begin{tabular}{|l|l|l|c|c|c|c|}
\hline Hypothesis & Path & Effect & \multicolumn{2}{|c|}{$\begin{array}{c}\text { High Price } \\
\text { Consciousness } \\
\text { Customers }\end{array}$} & \multicolumn{2}{|c|}{$\begin{array}{c}\text { Low Price } \\
\text { Consciousness } \\
\text { Customers }\end{array}$} \\
\cline { 4 - 8 } & & & \multicolumn{2}{|c|}{$\mathrm{t}$} & $\beta$ & $\mathrm{t}$ \\
\hline $9 \mathrm{a}$ & PU $\rightarrow$ Attitude & Strengthened & 0.385 & 7.789 & 0.4130 & 8.606 \\
\hline $9 \mathrm{~b}$ & PEOU $\rightarrow$ Attitude & Attenuated & 0.221 & 4.137 & 0.114 & 2.072 \\
\hline $9 \mathrm{c}$ & Social Influence $\rightarrow$ BI & Strengthened & 0.168 & 4.195 & 0.345 & 1.433 \\
\hline $9 \mathrm{~d}$ & Attitude $\rightarrow$ BI & Strengthened & 0.787 & 14.745 & 0.642 & 9.814 \\
\hline
\end{tabular}

Table 6: Results of Moderating Effects of Value Consciousness

\begin{tabular}{|c|c|c|c|c|c|c|}
\hline \multirow[t]{2}{*}{ Hypothesis } & \multirow[t]{2}{*}{ Path } & \multirow[t]{2}{*}{ Effect } & \multicolumn{2}{|c|}{$\begin{array}{c}\text { High Value } \\
\text { Consciousness Customers }\end{array}$} & \multicolumn{2}{|c|}{$\begin{array}{c}\text { Low Value } \\
\text { Consciousness } \\
\text { Customers }\end{array}$} \\
\hline & & & $\beta$ & $\mathrm{t}$ & $\beta$ & $\mathrm{t}$ \\
\hline $9 a$ & PU $\rightarrow$ Attitude & Strengthened & 0.402 & 9.960 & 0.408 & 6.295 \\
\hline $9 \mathrm{~b}$ & PEOU $\rightarrow$ Attitude & Strengthened & 0.167 & 3.897 & 0.189 & 2.391 \\
\hline $9 \mathrm{c}$ & Social Influence $\rightarrow$ BI & Strengthened & 0.256 & 6.732 & 0.241 & 3.615 \\
\hline $9 \mathrm{~d}$ & Attitude $\rightarrow$ BI & Strengthened & 0.688 & 14.180 & 0.696 & 10.035 \\
\hline
\end{tabular}

\section{Discussion and Conclusion}

The objective of this paper is to examine the moderating effect of price consciousness in the effectiveness of price discounts and premiums at different promotional benefit levels. To accomplish this objective, the responses of more and less price conscious consumers to price discounts and premiums across moderate and high benefit levels have been examined because there are few publications to date that have analyzed its moderating effect. On the whole, the results largely support our main predictions.

The results also show that consumers with higher levels of price / value consciousness have a higher intention to redeem m-coupons. This supports previous research done by Palazon and Delgado (2009). As the results of this study show, highly price-conscious consumers are likely to search for a better price regardless of the level of advertised discount. Given this tendency, it seems that offering a low price guarantee may be an effective method to reduce the search intentions of highly price-conscious consumers.

The current study contributes to contemporary research on the mobile coupons by offering insights into the factors that contribute to consumer usage. The results obtained have important implication for business and future research. The findings of the study strongly support the appropriateness of using the extended TAM model to understand the acceptance of mobile coupons from consumers' perspectives. First, we find that there is indirect effect of PU, PEOU, CP, PC on BI and direct effect on Attitude. SI, PI, COM, Attitude has a direct effect on BI. Social influence plays a very import role in behavioural intention. Based on the findings of this study, it appears that social influence has direct effects on consumer's behavioural intention. The results indicate that all the hypothesised relationships in the core model were confirmed. 
Table 7: Fit indices for measurement and structural models

\begin{tabular}{|l|c|c|}
\hline Fit indices & $\begin{array}{c}\text { Recommended } \\
\text { value }\end{array}$ & $\begin{array}{c}\text { Measurement } \\
\text { model }\end{array}$ \\
\hline$x$ 2/dr. & $\leq 3.60$ & 2.426 \\
\hline GFI & $\geq 0.90$ & 0.901 \\
\hline AGFI & $\geq 0.80$ & $0.98 \mathrm{C}$ \\
\hline FFT & $\geq 190$ & 0946 \\
\hline CFI & $>0.95$ & 0.968 \\
\hline RMSEA & $\leq 0.66$ & 0.043 \\
\hline HOELTER & $\geq 200$ & 349 \\
\hline
\end{tabular}

Table 8: Verification results of relationship of each construct

\begin{tabular}{|c|l|c|c|c|}
\hline Hypothesis & \multicolumn{1}{|c|}{ Relationship } & $\begin{array}{c}\text { Path } \\
\text { Coefficient }\end{array}$ & t-value & $p$ \\
\hline $\mathrm{H}_{1}$ & Perceived Usefulness $\rightarrow$ Attitude & 0.491 & 11.789 & 0.001 \\
\hline $\mathrm{H}_{2}$ & Perceived Ease of Use $\rightarrow$ Attitude & 0.171 & 4.351 & 0.001 \\
\hline $\mathrm{H}_{3}$ & Coupon Proneness $\rightarrow$ Attitude & 0.090 & 2.543 & 0.001 \\
\hline $\mathrm{H}_{4}$ & Perceived Credibility $\rightarrow$ Attitude & 0.169 & 5.436 & 0.001 \\
\hline $\mathrm{H}_{5}$ & Personal Innovativeness $\rightarrow \mathrm{BI}$ & 0.107 & 4.203 & 0.001 \\
\hline $\mathrm{H}_{6}$ & Social Influence $\rightarrow \mathrm{BI}$ & 0.222 & 7.476 & 0.001 \\
\hline $\mathrm{H}_{7}$ & Compatibility $\rightarrow \mathrm{BI}$ & 0.210 & 6.906 & 0.001 \\
\hline $\mathrm{H}_{8}$ & Attitude $\rightarrow \mathrm{BI}$ & 0.566 & 17.861 & 0.001 \\
\hline
\end{tabular}

Consistent with prior studies, perceived usefulness and perceived ease of use were found to be significant antecedents of the attitude towards m-coupons (e.g. Hsu, Wang and Wen 2006; Han, Yoon and Cameron, 2001; Venkatesh and Davis, 2000). This study supports prior research (e.g. Pikkarainen et al., 2006; Hsu, Wang and Wen 2006) which found the significant effect of perceived credibility on behavioural intention to use IT/IS in the context of mobile marketing.

The validated model provides a useful framework for managers needing to assess the possibility of success for m-coupon introductions, and to pro-actively design mobile coupon campaign. Results illustrate the importance of perceived usefulness related to the adoption of mobile coupons services.
Increasing the perceived usefulness of $\mathrm{m}$ coupon by potential customers is very important for mobile marketing practitioners. Social influence also plays a very important role in behavioural intention to redeem the mobile coupon. The attitude and behavior of consumers are still largely influenced by the endorsement of family and friends, marketing practitioners need to take into consideration when promoting the mobile coupons.

The ease of use of mobile coupons plays a significant part in adopting this new service. The cause of an underused m-coupon may be because potential users do not have enough knowledge resources required to use it. Furthermore, organizing education and training courses in various mobile computing technologies can facilitate people's familiarity 
with m-coupon applications and help them develop positive ease of use beliefs in the $\mathrm{m}$ coupons. The results also indicate that security and privacy issues are important concerns for consumers in using m-coupons. Mobile marketing practitioners need to get explicit permission from customers before they send the mobile coupons. Additionally, companies should overcome their concerns about spamming.

Although this study provides new insights into mobile coupon redemption, there are still various research avenues to pursue. The antecedents of mobile coupon behavioral intentions are similar for adopters and nonadopters. Motivation for not adopting mobile coupons which might illustrate different patterns and future research need to use different variables to study the reasons for not adopting this particular service. The second limitation concerns the sample. Although the sample size was quite large, it consisted of Malaysian consumers only. This has an effect on the generalization of the findings. An interesting avenue for further research could be, for example, a detailed study on mobile service usage across countries. The third limitation is our data contain intention measures rather than behavioral measures. Therefore follow up studies should consider using actual behavioral data. The study results proved several factors that markedly affect the behaviour and attitude of consumers in using m-coupons, which can be used for further research in the future.

Several interesting managerial implications can be derived. First of all, increasing the perceived usefulness of m-coupon by potential customers is very important for mobile marketing practitioners. Additionally, the significant moderating effects indicate that a segmentation approach might be very effective in reaching the customers to adopt m-coupons. The cause of an underused m-coupon may be because potential users do not have enough knowledge resources required to use it. Furthermore, organizing education and training courses in various mobile computing technologies can facilitate people's familiarity with m-coupon applications and help them develop positive ease of use beliefs in the m-coupons. The validated model provides a useful framework for managers needing to assess the possibility of success for m-coupon introductions, and to pro-actively design mobile coupon campaign. The study results proved several factors that markedly affect the behaviour and attitude of consumers in using m-coupons which can be used for further research in the future.

\section{References}

Ailawadi, K., Neslin, S.A. and Gedenk, K. (2001), "Pursuing the value-conscious consumer: store brands versus national brand promotions", Journal of Marketing, Vol. 65, pp. 71-89.

Alford, B.L., and Biswas, A. (2002), "The effects of discount level, price consciousness and sales proneness on consumers' price perception and behavioral intention", Journal of Business Research, Vol. 55 No.9, pp.775-83.

Amin H., (2007). "An analysis of mobile credit card usage intentions", Information Management \& Computer Security, 15(4), pp. 260-269.

Babakus, E., Tat, P.K., and Cunningham, W. (1988), "Coupon redemption: a motivational perspective", Journal of Consumer Marketing, Vol. 5 No.2, pp.37-43.

Bagozzi R., Baumgartner H., and Youjae Y. (1992). "State versus action orientation and the theory of reasoned action: An application to coupon usage," Journal of Consumer research, Vol.18, pp. 505-518.

Bawa K., Srinivasan S. S., and Srivastava R. K. (1997). "Coupon attractiveness and coupon proneness: A framework for modeling coupon redemption", Journal of Marketing Research, Nov, 34, 4, pp. 517-526.

Bedford D. W., (2005). Empirical investigation of the acceptance and intended use of mobile commerce: Location, personal privacy and trust, [Doctorial Dissertation], Mississippi State University, Mississippi.

Blattberg, R.C., and Neslin, S. (1990). Sales Promotion: Concepts, Methods, and Strategies, Prentice-Hall, Englewood Cliffs, NJ.

Bonnici, J., Compbell, D. P., and Fredenberger, W. B. (1996). Consumer issues in coupon usage: An exploratory analysis, Journal of Applied Business Research, 13, pp. 31-40.

Dickinger, A., Kleijnen, M. (2008), "Coupons Going Wireless: Determinants of consumer intentions to redeem mobile coupons", Journal of Interactive Marketing, vol. 22, issue 3, pp. 2339.

Dutta, S., Biswas, A. (2005), "Effects of low price guarantees on consumer post-purchase search intention: the moderating roles of value 
consciousness and penalty level", Journal of Retailing, Vol. 81 No.4, pp.283-91.

Guimond, L., Kim, C., Laroche, M. (2001), "An investigation of coupon-prone consumers: their reactions to coupon feature manipulations", Journal of Business Research, Vol. 54 No.2, pp.132-8.

Hair, J., Black, B. Babin, B., Anderson, R., and Tatham, R. (2006). Multivariate Data Analysis, ( $6^{\text {th }}$ edition), Upper Saddle River, NJ: PrenticeHall.

Han S. (2005). "Understanding User Adoption of Mobile Technology: Focusing on Physicians in Finland," Åbo Akademi University, [Doctorial dissertation], Finland.

Han, K.-H., Yoon, D., and Cameron, G. T. (2001). Web user's attitude and behavior toward online coupons, Proceedings of the American Academy of Advertising.

Hsu T., Wang Y., and Wen S. 2006. „Using the decomposed theory of planned behaviour to analyse consumer behavioural intention towards Mobile text message coupons", Journal of Targeting, Measurement and Analysis for Marketing, July, pp. 309.

Hung, S-Y., Ku, C-Y., and Chang, C-M. (2003), "Critical factors of WAP services adoption: an empirical study", Electronic Commerce Research and Applications, Vol. 2 No.1,

Kleijnen, Mirella, Wetzels, Martin, \& Ruyter, Ko de (2004). Consumer acceptance of wireless finance, Journal of financial services marketing, 8(3), pp. 206-217.

Kukar-Kinney M., and Grewal D., (2007), "Comparison of consumer reactions to pricematching guarantees in internet and bricks-andmortar retail environments," Journal of the Academy of Marketing Science, 35,2 , June, pp 197-207.

Kukar-Kinney, M., and Walters, R.G. (2003), "Consumer perceptions of refund depth and competitive scope in price-matching guarantees: effects on store patronage", Journal of Retailing, Vol. 79 pp.153-60.

Kwon H. S. and Chidambaram Laku. (2000). A Test of the Technology Acceptance Model: The Case of Cellular Telephone Adoption. Proceedings of the 33rd Hawaii International
Conference on System Sciences-Volume 1, pp.1023.

Lapczynski P.H. (2004). “An Integrated Model of Technology Acceptance for Mobile Computing”, Pace University, [Doctorial dissertation], New York, US.

Lichtenstein, D.R., Netemeyer, R.G., Burton, S. (1990), "Distinguishing coupon proneness from value consciousness: an acquisition-transaction utility theory perspective", Journal of Marketing, Vol. 54 No.3, pp.54-67.

Lin H., and Wang Y. (2005). Predicting Consumer Intention to Use Mobile Commerce in Taiwan, Proceedings of the International Conference on Mobile Business (ICMB'05), pp. 406-412.

MCMC (Malaysian Communications and multimedia commission), (2008). Communication and Multimedia: Selected facts and figures, Downloadable from http://www.skmm.gov.my/facts_figures/stats/ pdf/Quarter3_2008.pdf

Mittal, B. 1994. "An Integrated Framework for Relating Diverse Consumer Characteristics to Supermarket Coupon Redemption," Journal of Marketing Research, 31(Fall):533-44.

MMA, (2007), "Introduction to Mobile Coupons," Mobile Marketing Association, Available: www.mmaglobal.com

Narasimhan, C. (1984), "A price discrimination theory of coupons", Marketing Science, Vol. 3 pp.128 - 147.

Palazon M., and Delgado E., (2009), The moderating role of price consciousness on the effectiveness of price discounts and premium promotions, Journal of Product \& Brand Management, 18/4, 306-312.

Pedersen P.E. (2002). 'Adoption of mobile Internet services: An exploratory study of mobile commerce early adopters', downloadable from http://ikt.hia.no/perep/publications.htm\

Pikkarainen, T; Pikkarainen, K; Kirjaluoto, H; Pahnila, S (2004) "Consumer Acceptance of Online Banking: An Extension of the Technology Acceptance Model" in Internet Research Vol. 14, Issue 3, pp224-35. 
Shen Xiang and Chen Huaping (2008). An Empirical Study of What Drives Consumers to Use Mobile Advertising in China, The 3rd International Conference on Grid and Pervasive Computing - Workshops, IEEE Xplore, pp. 158163.

Shimp, Terence A. and Kanvas ALican (1984), "The Theory of Reasoned Action Applied to Coupon Usage," Journal of Consumer Research, 11 (December), pp. 795-809.
Sinha, I. and Batra, R. (1999), "The effect of consumer price consciousness on private label purchase", International Journal of Research in Marketing, Vol. 16, pp. 237-51.

Strother Neil, (2008) "Coupons: Identifying New Opportunities Beyond Early Trials," Jupiter Research Report.

Venkatesh, V. \& Davis, F.D. 2000. A theoretical extension of the technology acceptance model: Four longitudinal field studies. Management Science. 46(2). 186-204. 